\title{
Autoimmune Encephalitis With Psychotic Manifestations and Cognitive Impairment Presenting as Schizophrenia: Case Report and Literature Review
}

OPEN ACCESS

Edited by:

Izabela Guimaraes Barbosa, Federal University of Minas

Gerais, Brazi

Reviewed by:

Breno Fiuza Cruz,

Federal University of Minas

Gerais, Brazil

Sukhvir K. Wright,

Aston University, United Kingdom

*Correspondence:

Jun Xiao

1458935803@qq.com

Yuanyuan Luo

1107088906@qq.com

tThese authors have contributed equally to this work and share first authorship

\section{Specialty section: \\ This article was submitted to Schizophrenia, a section of the journal \\ Frontiers in Psychiatry}

Received: 01 December 2021

Accepted: 17 January 2022

Published: 14 February 2022

Citation:

Luo Y, Li J, Jiang F, Tan A, Qin X,

Xiao $X$, Wang Z, Wang P, Yi Y, Li J,

Yuan S, Liu L and Xiao J (2022)

Autoimmune Encephalitis With

Psychotic Manifestations and Cognitive Impairment Presenting as Schizophrenia: Case Report and Literature Review.

Front. Psychiatry 13:827138. doi: 10.3389/fpsyt.2022.827138
Yuanyuan Luo ${ }^{1,2 * \dagger}$, Jieying Li ${ }^{1,2 \dagger}$, Fugui Jiang ${ }^{1,2}$, Arui Tan ${ }^{1,2}$, Xiaohong Qin ${ }^{1,2}$, Xiaoqiang Xiao ${ }^{1,2}$, Zuxing Wang ${ }^{1,2}$, Peijia Wang ${ }^{1,2}$, Yang Yi ${ }^{1,2}$, Juan Li $^{1,2}$, Shuai Yuan ${ }^{3}$, Lei Liu ${ }^{4}$ and Jun Xiao ${ }^{1,2 *}$

'Sichuan Provincial Center for Mental Health, Sichuan Academy of Medical Science \& Sichuan Provincial People's Hospital, Chengdu, China, ${ }^{2}$ Key Laboratory of Psychosomatic Medicine, Chinese Academy of Medical Sciences, Chengdu, China, ${ }^{3}$ The Fourth People's Hospital of Chengdu, Chengdu, China, ${ }^{4}$ Department of Neurology, Beijing Tongren Hospital, Capital Medical University, Beijing, China

Autoimmune encephalitis is characterized by mental and behavioral symptoms, seizures, and cognitive impairment. The presence of schizophrenia needs to be distinguished from that of autoimmune encephalitis. Herein, we describe the case of a woman who exhibited abnormal mental behavior and cognitive impairment. The patient had experienced similar symptoms more than 20 years previously and had been diagnosed with schizophrenia. The patient's psychotic symptoms improved after treatment with antipsychotic drugs; however, cognitive impairment persisted. She was diagnosed with anti-N-methyl-D-aspartate (NMDA)-receptor concurrent with anti- $\alpha$-amino-3-hydroxy-5-methyl-4-isoxazolepropionic acid (AMPA)-receptor encephalitis. She showed improvement after treatment with steroids and intravenous immunoglobulins (IVIgs). Furthermore, we reviewed the literature and found that, including the present case, 10 patients have been diagnosed with anti-NMDA concurrent with anti-AMPA-receptor encephalitis. Three of these patients were men and seven were women, and their ages ranged from 21 to 71 years. Moreover, seven (70\%) patients had a history of tumors. Symptoms of these patients included psychotic symptoms, varying degrees of consciousness disturbance, seizures, dyskinesia, dystonia, autonomic dysfunction, agitation, and verbal reduction. Brain magnetic resonance imaging findings showed scattered fluid-attenuated inversion recovery hyperintensity in subcortical white matter and/or medial temporal lobe in seven (70\%) patients. After combination treatment, including tumor removal and administration of steroids, IVIg, plasma exchange, or immunity inhibitors, the symptoms improved in part of the patients. It is necessary to exclude autoimmune encephalitis for patients with psychiatric manifestations and cognitive impairment. Timely combination therapy is important in anti-NMDA-receptor concurrent with anti-AMPA-receptor encephalitis.

Keywords: autoimmune encephalitis, anti-AMPAR encephalitis, anti-NMDAR encephalitis, schizophrenia, psychotic 


\section{INTRODUCTION}

Autoimmune encephalitis is associated with antibodies against neuronal cell-surface or synaptic proteins, including neurotransmitter receptors; this disorder can develop with core symptoms that are similar to those of infectious encephalitis, including mental symptoms, cognitive impairment, and epilepsy $(1,2)$. Some neuronal surface antigens associated with this condition have been identified as follows: N-methyl-Daspartate (NMDA) receptor, $\alpha$-amino-3-hydroxy-5-methyl4-isoxazolepropionic acid (AMPA) receptor, metabotropic glutamate receptor, contactin-associated protein-like 2 (Caspr2), gamma-aminobutyric acid-B (GABAb) receptor, glycine receptor, leucine-rich glioma-inactivated 1 (LGI1) $(3,4)$. The symptoms caused by these antibodies are similar to those of schizophrenia, dementia, and sleep disorders (5-7).

NMDA, AMPA, and metabotropic glutamate receptors are the major excitatory neurotransmitter glutamate receptors of the central nervous system. NMDA receptors are ligands and voltage-gated ionotropic receptors that promote the influx of $\mathrm{Ca}^{2+}$ and $\mathrm{Na}^{+}(8,9)$ and play a key physiological role in synaptic functions such as synaptic plasticity, learning, and memory (10). Patients with anti-NMDA-receptor encephalitis present with abnormal (psychiatric) behaviors or cognitive dysfunction; speech dysfunction (pressured speech, verbal reduction, or mutism); seizures; movement disorders, dyskinesia, rigidity, or abnormal postures; decreased level of consciousness; and autonomic dysfunction or central hypoventilation $(10,11)$. In addition, AMPA-type ionotropic glutamate receptors, which are the major brain excitatory neurotransmitter receptors, are tetrameric ligand-gated ion channels comprising GluA1-4 subunits (12). Patients with anti-AMPA-receptor encephalitis mainly present with short-term memory loss, confusion, mood disturbances, sleep disorders, seizures, and psychosis $(13,14)$.

Previous studies have found that patients with no or minimal neurological features who have tested positive for neuronal autoantibodies show sufficient differences from typical autoimmune encephalitis and have proposed a novel category of autoimmune psychosis $(15,16)$. Pollak et al. proposed a novel and conservative approach to recognize autoimmune psychosis (16). However, it was found that the criteria for autoimmune psychosis have limited utility in the absence of neurological symptoms or when paraclinical test results are normal (17). Another study had revealed that anti-NMDAreceptor encephalitis as defined by consensus criteria rarely occurred in psychiatric patients (18). In addition, there were no differences between seropositive and seronegative anti-NMDAreceptor antibodies patients in the score improvement for Positive and Negative Syndrome Scale after completing 4 weeks of amisulpride treatment (19). Therefore, further studies are required to identify the characteristics of autoimmune psychosis.

Psychotic manifestations are often observed among patients with autoimmune disorders $(20,21)$. Anti-NMDA-receptor encephalitis might be present in a subset of patients with psychosis, and immunotherapy can be considered a treatment option for patients who fail to respond to other therapies (22). Moreover, although pure psychotic manifestations of antibody-associated autoimmune encephalitis without any additional neuropsychiatric findings are rare (23), it is easy to overlook autoimmune encephalitis, particularly when the neurological symptoms are atypical. In this study, we present our experience with a patient with autoimmune encephalitis who was initially diagnosed with schizophrenia and also review previous cases.

\section{CASE PRESENTATION}

A 50-year-old woman presented to the hospital with slow reaction, memory deterioration, sleep disorder, mood disturbances, and abnormal behaviors including repetitive stereotyped words and behaviors, decreased social interaction, and incontinence (Figure 1). The patient's condition worsened before the diagnosis of encephalitis was made. Worsening was indicated by mutism, reduced activity, movement disorder, dystonia, incontinence, confusion, seizures, and autonomic dysfunction. The modified Rankin Scale (mRS) $(24,25)$ score was 4. Notably, the patient had experienced similar symptoms $>20$ years previously and was diagnosed with schizophrenia. The diagnostic criteria referred to International Classification of diseases. The main symptoms previously were mood disturbances (anxiety and fear), abnormal behaviors (repetitive stereotyped behaviors, decreased social interaction, and catatonic stupor), verbal reduction, slow reaction, and memory deterioration, and after treatment with antipsychotic drugs, the patient's mental symptoms improved, but persistent cognitive impairment was noted. In addition, the patient had a history of a hydatidiform mole that was surgically removed 15 years previously.

Blood test results showed normal levels of antinuclear antibodies and comprehensive metabolism. The presence of tumors was ruled out via chest and abdomen computed tomography and breast ultrasound. Video electroencephalography showed an epilepsy wave. Initial cerebrospinal fluid (CSF) study revealed that lymphocyte count increased with normal protein (total protein, $0.478 \mathrm{~g} / \mathrm{L}$; glucose, $3.77 \mathrm{mmol} / \mathrm{L}$; chlorine $127.0 \mathrm{mmol} / \mathrm{L}$; nucleated cell at 70 cells $/ \mu \mathrm{L}$ including $8 \%$ neutrophils and $85.2 \%$ lymphocytes). Infection studies revealed negative results for cryptococcus and tuberculosis as well as other bacteria and fungi. Investigation for autoimmune encephalitis was performed by collecting antibodies, including LGI1 protein, GABAb receptor, NMDA receptor, Caspr2, AMPA1 receptor, AMPA2 receptor, Hu, Yo, $\mathrm{Ri}, \mathrm{CV} 2, \mathrm{Ma} 2$, and amphiphysin from the serum and CSF. AntiAMPA receptor 2 (1:32) (Figure 2A) and anti-NMDA receptor (1:32) (Figure 2B) antibodies were detected in the CSF, and anti-AMPA receptor 2 (1:32) was detected in serum (Figure 2C).

The patient was started on high-dose steroid therapy on the 10th day after onset, and the dose was subsequently and gradually reduced (Figure 1). After 1 month, her cognitive function (total scores on Mini-mental State Examination and Montreal Cognitive Assessment were 5 and 3, respectively) and movement disorder were partially improved. Abnormal behaviors were not observed, although the patient still showed verbal reduction, 


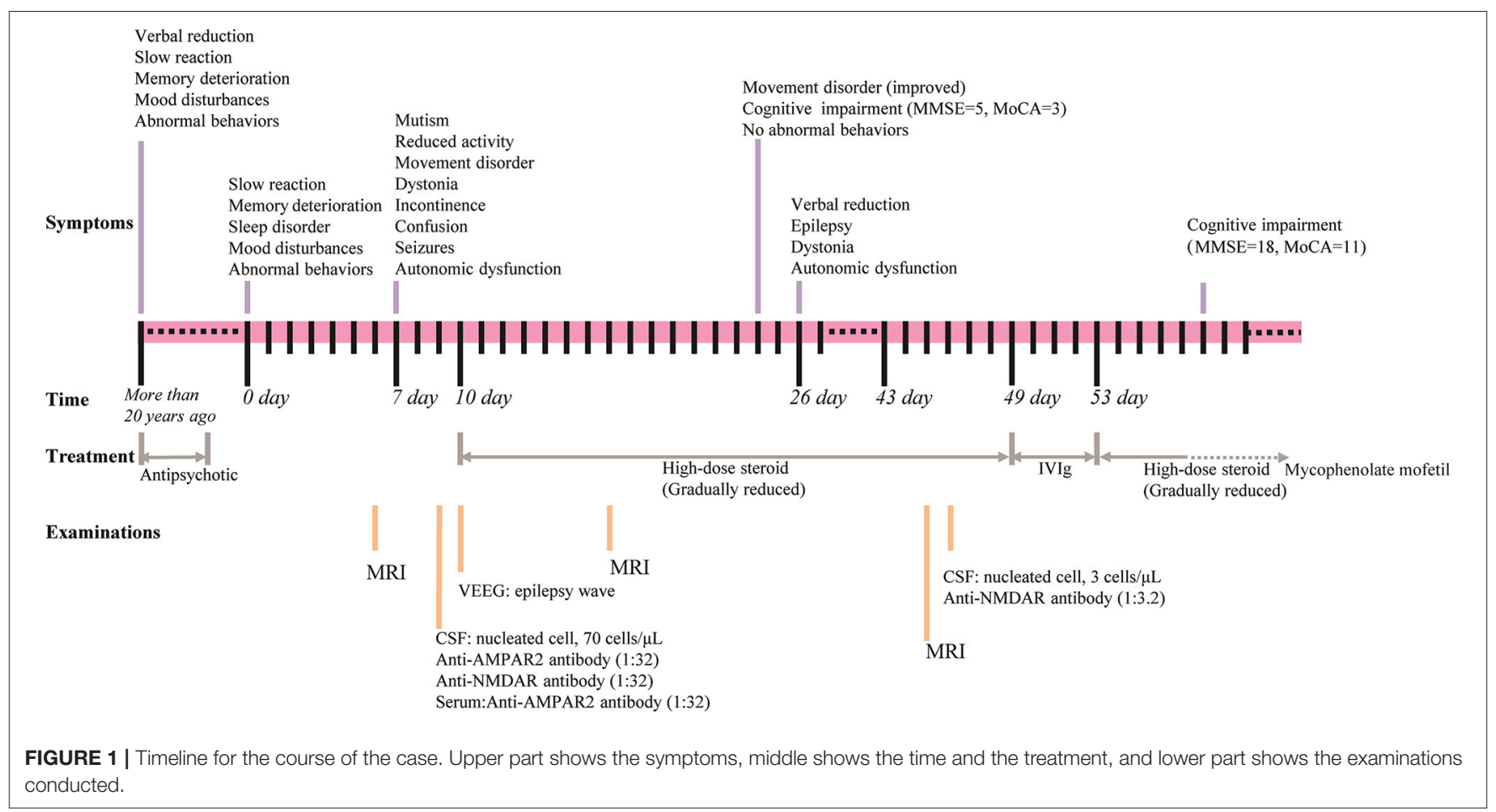

epilepsy, dystonia, and autonomic dysfunction. Brain magnetic resonance imaging (MRI) revealed that scattered fluid-attenuated inversion recovery (FLAIR) hyperintensity had increased in the subcortical white matter and medial temporal lobe at 17 days (Figure 3B) and 45 days (Figure 3C) after onset compared with 6 days (Figure 3A) after onset. Moreover, repeated CSF analysis revealed that anti-NMDA receptor antibody (1:3.2) was positive but anti-AMPA1 and anti-AMPA2 receptor antibodies were negative. Thereafter, a combination treatment including intravenous immunoglobulin (IVIg) at $2 \mathrm{~g} / \mathrm{kg}$ for 5 days, steroids, and a second-line drug (mycophenolate mofetil) was administered. At the last follow-up, cognitive function was improved (total scores on Mini-mental State Examination and Montreal Cognitive Assessment were 18 and 11, respectively), and no abnormal mental symptoms, dystonia, seizures, and autonomic dysfunction were noted. The patient's mRS score was 2. The disease did not recur during the 30 weeks of follow-up.

\section{REVIEW OF PREVIOUSLY REPORTED CASES OF ANTI-AMPA CONCURRENT WITH ANTI-NMDA-RECEPTOR ENCEPHALITIS}

To evaluate the clinical characteristics and outcome of antiAMPA concurrent with anti-NMDA-receptor encephalitis in the clinical setting, we reviewed the previously reported studies $(13,26,27)$. Including our patient, 10 patients with anti-AMPAreceptor concurrent with anti-NMDA-receptor encephalitis have been reported, but only 4 had complete clinical data (Table 1).
Three patients were men and seven were women, giving a mento-women ratio of 3:7. The ages of the patients ranged from 21 to 71 years. Seven (70\%) patients showed abnormal brain MRI, eight (80\%) had tumors, and one had a hydatidiform mole. All patients had varying degrees of consciousness disturbance (100\%). Four patients for whom complete clinical data were available had seizures (100\%), three had dyskinesia (75\%), three had dystonia (75\%), two had psychiatric symptoms (50\%), two showed verbal reduction (50\%), one had autonomic dysfunction and agitation, and one required intubation. After combined treatment, which included tumor resection and administration of steroids, IVIg, plasma exchange, cyclophosphamide, infusion of rituximab, or another second-line options, three patients showed complete response to the treatment, six patients showed partially response, and one patient died of neuroblastoma.

\section{DISCUSSION}

Autoimmune encephalitis is associated with many disorders and has been detected in patients with Alzheimer's disease (6), schizophrenia (5), bipolar disorder (28), and depression (29). Previous studies found that multiple antibodies, including glial and neuronal surface antibodies, can appear at the same time in patients with autoimmune encephalitis (26). Our patient presented with cognitive impairment, mood disturbances, speech dysfunction, sleep disorder, dystonia, autonomic dysfunction, and epilepsy. Moreover, the patient's CSF test was positive for anti-NMDA-receptor concurrent with anti-AMPA-receptor antibodies. The patient's symptoms improved after combination treatment with steroids and IVIg. Surprisingly, the patient had shown similar symptoms previously, resulting in her being 


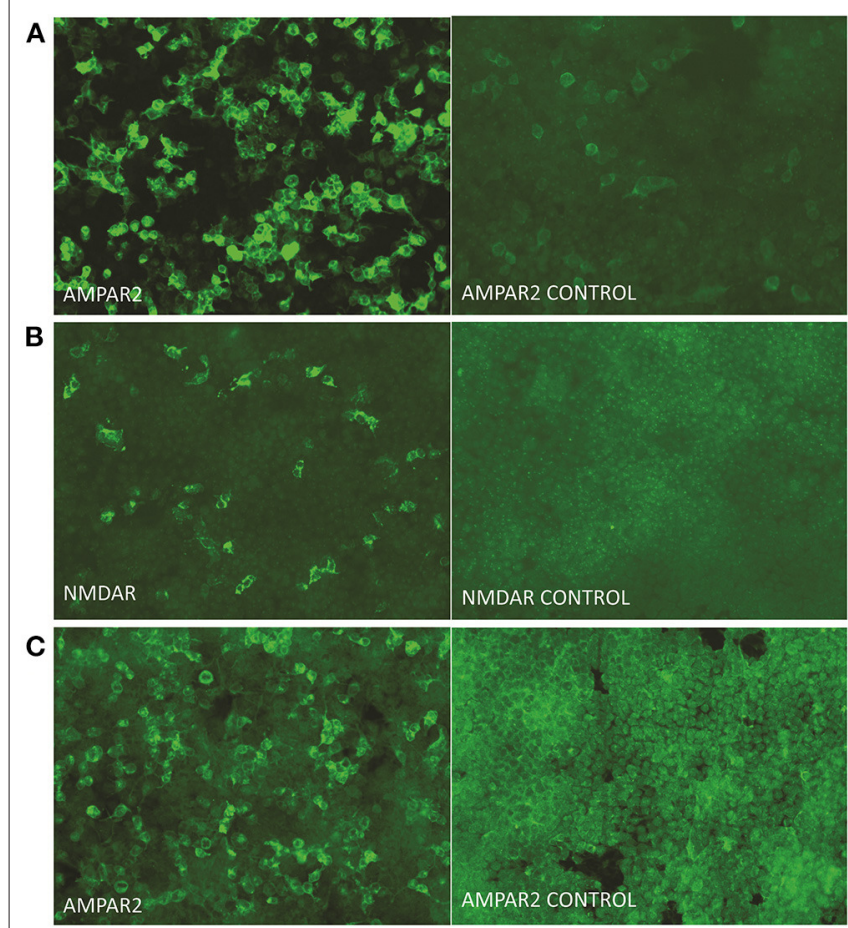

FIGURE 2 | Presence of autoimmune antibodies in serum and CSF. Immunoactivity of the anti-AMPA-receptor 2 antibody (A), anti-NMDA-receptor antibody (B) in cerebrospinal fluid, and anti-AMPA-receptor 2 antibody in serum (C) at 9 days after onset. The titer of antibodies in the cerebrospinal fluid and serum were measured as 1:32 (original magnification, 200x).

diagnosed with schizophrenia. Her symptoms alleviated after treatment with antipsychotic drugs, but cognitive impairment and mood disorder were still noted.

Previous studies indicated that patients diagnosed with bipolar disorder, autistic traits, or psychotic disorder presented with autoimmune encephalitis a few years after the original diagnosis $(20,22,28,30)$, demonstrating that autoimmune encephalitis with prevalent psychiatric manifestations may be misdiagnosed and mistreated. Anti-NMDA-receptor encephalitis frequently has a relapsing course (30-32). During recovery, patients still present with alterations in behavior, memory, cognition, and executive functions (33). However, anti-AMPA-receptor encephalitis results in rapid deterioration of neurological function $(14,34)$. Research has revealed that anti-NMDAR IgA antibody in the brain likely interferes with neuronal function without causing acute neuronal degeneration or inflammatory changes and results in slow progressive cognitive impairment (35). Therefore, it is speculated that the patient may had anti-NMDA-receptor encephalitis but not anti-AMPA-receptor encephalitis $>20$ years previously. Patients with acute onset, atypical course of illness, neuropsychiatric symptoms, cognitive impairment, and rapid deterioration should be screened for autoimmune encephalitis $(28,36)$.

Ionotropic glutamate receptors are integral membrane proteins with a tetrameric structure containing four discrete
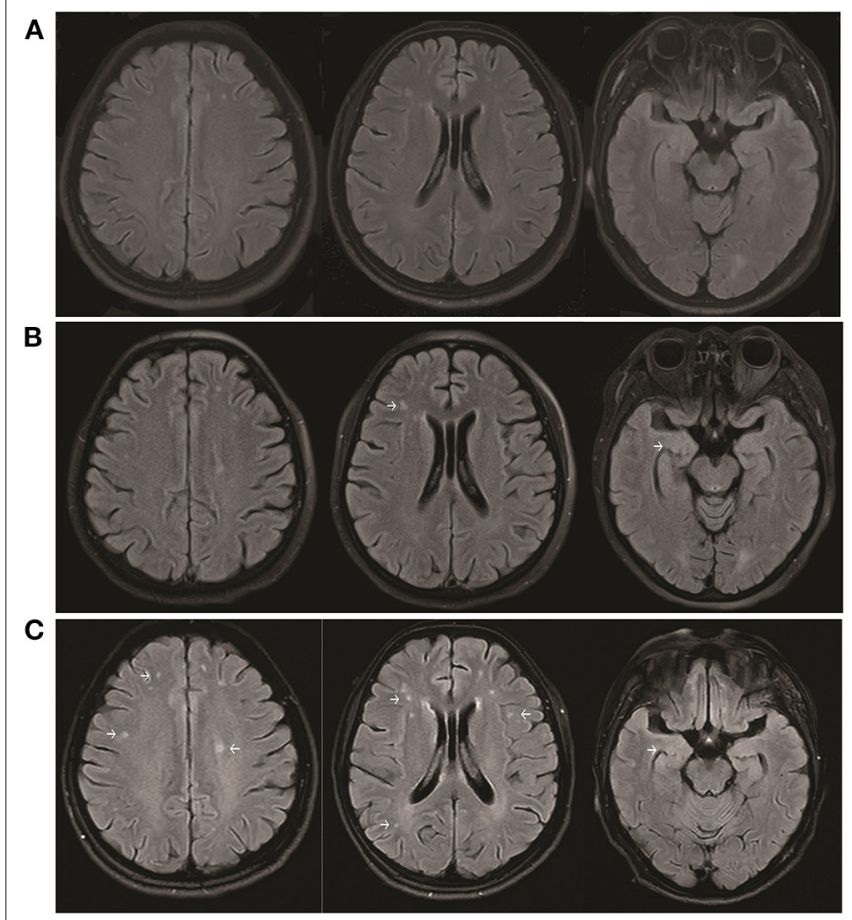

FIGURE 3 | Brain MRI showing increased scattered fluid-attenuated inversion recovery hyperintensity in the subcortical white matter and medial temporal lobe at 17 days (B) and 45 days (C) after onset compared with 6 days (A) after onset.

semiautonomous domains: the extracellular amino-terminal, extracellular ligand-binding, transmembrane, and intracellular carboxyl-terminal domains (12). Sequences are similar among all glutamate receptor subunits, including AMPA, kainate, NMDA, and $\delta$ receptor (12). The antigens on the surface of the same cell can be simultaneously or successively affected when the immune system is abnormal (37). Jones et al. displayed a model of active immunization exists which developed a fulminant encephalitis; which is characterized by B-cell infiltrates, plasma cells, microglial activation, $\mathrm{CD}^{+}{ }^{+} \mathrm{T}$ cells, rare neuronal loss, and antibodies against several epitopes of the GluN1 and GluN2 subunits of the NMDA receptor (38). Therefore, we speculated that receptors with the same structure might be affected at the same time in abnormal immune environments. Tumors and herpes simplex encephalitis can result in abnormal immunity $(39,40)$. The pathogenesis of autoimmune encephalitis is related to herpes simplex virus infection and tumors such as lung cancer, breast cancer, ovarian teratoma, and thymic cancer $(3,26,41)$. Tumors often show anti-AMPA receptors and other additional antibodies at the same time (13). Literature review also showed that 8 of 10 patients had tumors. Therefore, it is necessary to screen tumors when two antibodies are identified.

AMPA receptor mediates most of the fast excitatory synaptic transmission in the brain and is important for synaptic plasticity, memory, and learning $(42,43)$. Anti-AMPA-receptor encephalitis manifests as limbic encephalitis with short-term 
TABLE 1 | Clinical features of patients with anti-AMPA-receptor concurrent with anti-NMDA-receptor encephalitis.

\begin{tabular}{|c|c|c|c|c|c|c|c|c|c|}
\hline No. & Age/sex & $\begin{array}{l}\text { Symp } \\
\text { until } \\
\text { (weel }\end{array}$ & $\begin{array}{l}\text { ton onset } \\
\text { liagnosis } \\
\text { ) }\end{array}$ & resentation & MRI & & EEG & CSF & \\
\hline 1 & $25 / F$ & 2 & $\begin{array}{l}\text { Psyc } \\
\text { agita } \\
\text { seizl } \\
\text { hype } \\
\text { intuk }\end{array}$ & $\begin{array}{l}\text { confusion, } \\
\text { jerbal reduction, } \\
\text { yyskinesias, fever, } \\
\text { on, required }\end{array}$ & Normal & & NA & Normal & \\
\hline 2 & $71 / \mathrm{M}$ & 5 & $\begin{array}{l}\text { Som } \\
\text { diso }\end{array}$ & $\begin{array}{l}\text { t, seizures, } \\
\text { d, tremor }\end{array}$ & $\begin{array}{l}\text { Abnormality in the hypothalar } \\
\text { mass effect on pituitary glano } \\
\text { increased signal in the right t }\end{array}$ & $\begin{array}{l}\text { egion with } \\
\text { /FLAIR } \\
\text { oral lobe }\end{array}$ & $\begin{array}{l}\text { Generalized } \\
\text { slowing }\end{array}$ & Normal & protein \\
\hline 3 & $50 / F$ & 1 & $\begin{array}{l}\text { Muti } \\
\text { mov } \\
\text { dyst } \\
\text { conf } \\
\text { auto }\end{array}$ & $\begin{array}{l}\text { duced activity, } \\
\text { disorder, } \\
\text { ncontinence, } \\
\text { seizures, } \\
\text { dysfunction }\end{array}$ & $\begin{array}{l}\text { FLAIR hyperintensity scattere } \\
\text { subcortical white matter, mec }\end{array}$ & $\begin{array}{l}\text { thin } \\
\text { emporal lobe }\end{array}$ & Epilepsy wave & $\begin{array}{l}\text { Nucleat } \\
8 \% \text { neu }\end{array}$ & $\begin{array}{l}\mathrm{s} / \mu \mathrm{L} \text {, including } \\
\% \text { lymphocytes }\end{array}$ \\
\hline 4 & 30/M & NA & $\begin{array}{l}\text { Diffic } \\
\text { unar } \\
\text { spas } \\
\text { abnc }\end{array}$ & $\begin{array}{l}\text { alking, seizures, } \\
\text { le, increased } \\
\text { neuropsychiatric } \\
\text { ies }\end{array}$ & $\begin{array}{l}\text { Brain MRI revealed FLAIR hy } \\
\text { scattered within mostly the st } \\
\text { matter as well as an enhancir } \\
\text { to the left caudate nucleus }\end{array}$ & $\begin{array}{l}\text { tensity } \\
\text { ortical white } \\
\text { sion adjacent }\end{array}$ & NA & $\begin{array}{l}\text { WBC } 97 \\
70 \mathrm{mg} / \mathrm{c}\end{array}$ & $\begin{array}{l}\text { cytes), protein } \\
\text { e } 65 \mathrm{mg} / \mathrm{dL}\end{array}$ \\
\hline $5-10^{*}$ & $(21-61) / 5 F, 1 M$ & NA & $\begin{array}{l}\text { Seve } \\
\text { anti- } \\
\text { ence } \\
\text { level } \\
\text { decr } \\
\text { inter } \\
\text { ocul }\end{array}$ & $\begin{array}{l}\text { mptoms of } \\
\text { A receptor } \\
\text { is, consciousness } \\
\text { patients } \\
\text {, and required } \\
\text { are. } 1 \text { case had } \\
\text { scle weakness. }\end{array}$ & 4 Pts: bilateral medial tempor & bes & NA & NA & \\
\hline No. & Antibodies & & Tumor & $\begin{array}{l}\text { Symptom onset until } \\
\text { start of treatment } \\
\text { (week) }\end{array}$ & $\begin{array}{l}\text { Neurologic outcome } \\
\text { measuring mRS } \\
\text { (compared with mRS } \\
\text { at diagnosis) }\end{array}$ & Therapy & & $\begin{array}{l}\text { Treatment } \\
\text { response }\end{array}$ & $\begin{array}{l}\text { Follow-up, } \\
\text { (week) }\end{array}$ \\
\hline 1 & AMPAR, NMDAR & & Ovarian teratoma & 2 & $0(5)$ & Tumor resect & eroids, IVlg & Full & 50 \\
\hline 2 & AMPAR, NMDAR & & Thymic carcinoid & 3 & $1(4)$ & $\begin{array}{l}\text { Tumor resect } \\
\text { plasma excha }\end{array}$ & roids, & Full & 78 \\
\hline 3 & AMPAR, NMDAR & & Hydatid mole & 1.5 & $2(4)$ & IVlg, steroide & hd line & Full & 30 \\
\hline 4 & AMPAR, VGKCR, NMDAR & & Thymoma & NA & NA & $\begin{array}{l}\text { Tumor resect } \\
\text { cyclophosph } \\
\text { rituximab }\end{array}$ & $\begin{array}{l}\text { eroids, IVlg, } \\
\text { infusion of }\end{array}$ & Part & 8 \\
\hline $5-10^{\star}$ & AMPAR, NMDAR & & $\begin{array}{l}4 \text { Pts: ovarian } \\
\text { teratoma; } 1 \text { breast } \\
\text { cancer; } 1 \text { GABAbR-Ab }\end{array}$ & NA & $\begin{array}{l}5 \text { Pts: mRS score } \\
4(0-6) ; 1 \text { died of } \\
\text { neuroblastoma }\end{array}$ & $\begin{array}{l}6 \text { Pts: first lin } \\
\text { line; } 5 \text { Pts tur }\end{array}$ & $\begin{array}{l}\text { s: second } \\
\text { noval }\end{array}$ & NA & NA \\
\hline
\end{tabular}

"The 5-10 cases did not have complete data.

F, female; M, male; WBC, white blood cell; Pts, patients; FLAIR, fluid-attenuated inversion recovery; mRS, modified Rankin Scale; IVIg, intravenous immunoglobulins. 
memory loss, confusion, mood disturbances, epilepsy, psychosis, and sleep disorders $(7,13)$. Patients with anti-AMPA-receptor encephalitis may exhibit rapid deterioration of neurological function and present with additional antibodies (14, 34). Höftberger et al. revealed that the coexistence of onconeuronal antibodies predicted a poor outcome (13). AMPA receptorsdependent depolarization can remove the inhibition of NMDA receptors which are blocked by $\mathrm{Mg}^{2+}$ at resting potential (12), and NMDA receptors act as coincident detectors that sense postsynaptic depolarization at the same time or shortly after the release of glutamate or other excitatory amino acids. This process allows NMDA receptors to mediate cellular mechanisms of learning and memory $(8,12)$. We speculated that this may be the reason for the rapid deterioration of our patient's condition.

AMPA and NMDA receptors distributed in multiple areas of the brain, and the receptors in the corresponding parts showed corresponding symptoms. The presence of NMDA receptors in the presynapse is observed in several areas of the brain, such as the cortex, hippocampus, cerebellum, and spinal cord (9). AMPA receptors are broadly distributed in the cortex, hippocampus, cerebellum, basal ganglia (44) and peripheral nervous system (45). Previous studies displayed that the brain MRI in anti-AMPA and anti-NMDA-receptor encephalitis revealed a scattered FLAIR hyperintensity within mostly the subcortical white matter (27) and temporal lobe (13), which were consistent with our patient.

Early treatment and no admission to an intensive care unit were identified as predictors of good outcome $(46,47)$. The symptoms of our patient also improved markedly through early treatment. Literature review found that patients respond well to treatment in the third week after onset. Therapy usually combined two or more treatment options, including tumor resection, steroids, IVIg, plasma exchange, cyclophosphamide, infusion of rituximab, or other second-line options. The study case also showed that combination treatment could improve symptoms more than single treatment could. Therapeutic plasma exchange might be an effective rescue therapy to rapidly improve the symptoms of patients with severe steroid/IVIG

\section{REFERENCES}

1. Graus F, Titulaer MJ, Balu R, Benseler S, Bien CG, Cellucci T, et al. A clinical approach to diagnosis of autoimmune encephalitis. Lancet Neurol. (2016) 15:391-404. doi: 10.1016/S1474-4422(15)00401-9

2. Gardoni F, Stanic J, Scheggia D, Benussi A, Borroni B, Di Luca M. NMDA and AMPA receptor autoantibodies in brain disorders: from molecular mechanisms to clinical features. Cells. (2021) 10:77. doi: $10.3390 /$ cells 10010077

3. Lancaster E, Martinez-Hernandez E, Dalmau J. Encephalitis and antibodies to synaptic and neuronal cell surface proteins. Neurology. (2011) 77:179-89. doi: 10.1212/WNL.0b013e318224afde

4. Michael S, Waters P, Irani SR. Stop testing for autoantibodies to the VGKCcomplex: only request LGI1 and CASPR2. Pract Neurol. (2020) 20:377-84. doi: 10.1136/practneurol-2019-002494

5. Kayser MS, Dalmau J. Anti-NMDA receptor encephalitis, autoimmunity, and psychosis. Schizophr Res. (2016) 176:36-40. doi: 10.1016/j.schres.2014. 10.007 refractory antibody-associated autoimmune encephalitis (48). It was speculated that early combination therapy would have a better outcome, high survival rate, and low recurrence rate (47). However, long-term follow-up is necessary to observe the improvement of neurological dysfunctions.

In general, patients with anti-NMDA-receptor concurrent with anti-AMPA-receptor encephalitis present with abundant symptoms and often have a history of tumors. Most of them had positive brain MRI results. With timely combination therapy, patients should have a good outcome. The results of the present study indicate the necessity to exclude autoimmune encephalitis for first-episode psychosis and to screen the tumors while antiNMDA receptor is concurrent with anti-AMPA receptor. This case emphasized the importance of identifying autoimmune encephalitis in patients with schizophrenia and provided insights into the treatment of anti-NMDA-receptor concurrent with antiAMPA-receptor encephalitis.

\section{DATA AVAILABILITY STATEMENT}

The original contributions presented in the study are included in the article/supplementary material, further inquiries can be directed to the corresponding authors.

\section{ETHICS STATEMENT}

The studies involving human participants were reviewed and approved by Ethics Committee of Sichuan Provincial People's Hospital. The patients/participants provided their written informed consent to participate in this study. Written informed consent was obtained from the individual(s) for the publication of any potentially identifiable images or data included in this article.

\section{AUTHOR CONTRIBUTIONS}

All authors listed have made a substantial, direct, and intellectual contribution to the work and approved it for publication.

6. Palese F, Bonomi E, Nuzzo T, Benussi A, Mellone M, Zianni E, et al. Anti-GluA3 antibodies in frontotemporal dementia: effects on glutamatergic neurotransmission and synaptic failure. Neurobiol Aging. (2020) 86:143-55. doi: 10.1016/j.neurobiolaging.2019.10.015

7. Muñoz-Lopetegi A, Graus F, Dalmau J, Santamaria J. Sleep disorders in autoimmune encephalitis. Lancet Neurol. (2020) 19:1010-22. doi: 10.1016/S1474-4422(20) 30341-0

8. Paoletti P, Bellone C, Zhou Q. NMDA receptor subunit diversity: impact on receptor properties, synaptic plasticity and disease. Nat Rev Neurosci. (2013) 14:383-400. doi: 10.1038/ nrn3504

9. Franchini L, Carrano N, Di Luca M, Gardoni F. Synaptic GluN2AContaining NMDA receptors: from physiology to pathological synaptic plasticity. Int J Mol Sci. (2020) 21:1538. doi: 10.3390/ijms21 041538

10. Hansen KB, Yi F, Perszyk RE, Furukawa H, Wollmuth LP, Gibb $\mathrm{AJ}$, et al. Structure, function, and allosteric modulation of NMDA 
receptors. J Gen Physiol. (2018) 150:1081-105. doi: 10.1085/jgp.20 1812032

11. Dalmau J, Armangué T, Planagumà J, Radosevic M, Mannara F, Leypoldt $F$, et al. An update on anti-NMDA receptor encephalitis for neurologists and psychiatrists: mechanisms and models. Lancet Neurol. (2019) 18:1045-57. doi: 10.1016/S1474-4422(19)30244-3

12. Traynelis SF, Wollmuth LP, McBain CJ, Menniti FS, Vance KM, Ogden KK, et al. Glutamate receptor ion channels: structure, regulation, and function. Pharmacol Rev. (2010) 62:405-96. doi: 10.1124/pr.109.002451

13. Höftberger R, van Sonderen A, Leypoldt F, Houghton D, Geschwind M, Gelfand J, et al. Encephalitis and AMPA receptor antibodies: Novel findings in a case series of 22 patients. Neurology. (2015) 84:2403-12. doi: 10.1212/WNL.0000000000001682

14. Yang S, Qin J, Li J, Gao Y, Zhao L, Wu J, et al. Rapidly progressive neurological deterioration in anti-AMPA receptor encephalitis with additional CRMP5 antibodies. Neurol Sci. (2016) 37:1853-5. doi: 10.1007/s10072-0162680-0

15. Al-Diwani A, Pollak TA, Langford AE, Lennox BR. Synaptic and neuronal autoantibody-associated psychiatric syndromes: controversies and hypotheses. Front Psychiatry. (2017) 8:13. doi: 10.3389/fpsyt.201 7.00013

16. Pollak TA, Lennox BR, Müller S, Benros ME, Prüss H, Tebartz van Elst L, et al. Autoimmune psychosis: an international consensus on an approach to the diagnosis and management of psychosis of suspected autoimmune origin. Lancet Psychiatry. (2020) 7:93-108. doi: 10.1016/S2215-0366(19) 30290-1

17. Guasp M, Giné-Servén E, Maudes E, Rosa-Justicia M, Martínez-Hernández E, Boix-Quintana E, et al. Clinical, neuroimmunologic, and CSF investigations in first episode psychosis. Neurology. (2021) 97:e61-75. doi: 10.1212/WNL.000000000 0012191

18. Kelleher E, McNamara P, Dunne J, Fitzmaurice B, Heron EA, Whitty P, et al. Prevalence of N-methyl-d-aspartate receptor antibody (NMDAR-Ab) encephalitis in patients with first episode psychosis and treatment resistant schizophrenia on clozapine, a population based study. Schizophr Res. (2020) 222:455-61. doi: 10.1016/j.schres.2019.11.023

19. Pollak TA, Vincent A, Iyegbe C, Coutinho E, Jacobson L, Rujescu D, et al. Relationship between serum NMDA receptor antibodies and response to antipsychotic treatment in first-episode psychosis. Biol Psychiatry. (2021) 90:9-15. doi: 10.1016/j.biopsych.2020.11.014

20. Mayorova MA, Butoma BG, Churilov LP, Gilburd B, Petrova NN, Shoenfeld Y. Autoimmune concept of schizophrenia: historical roots and current facets. Psychiatr Danub. (2021) 33:3-17. doi: 10.24869/psyd.2021.3

21. Steiner J, Prüss H, Köhler S, Frodl T, Hasan A, Falkai P. Autoimmune encephalitis with psychosis: warning signs, step-by-step diagnostics and treatment. World J Biol Psychiatry. (2020) 21:241-54. doi: 10.1080/15622975.2018.1555376

22. Murashko AA, Pavlov KA, Pavlova OV, Gurina OI, Shmukler A. Antibodies against N-Methyl D-aspartate receptor in psychotic disorders: a systematic review. Neuropsychobiology. (2021) 17:1-18. doi: 10.1159/00 0515930

23. Bien CG, Rohleder C, Mueller JK, Bien CI, Koethe D, Leweke FM. Neural autoantibodies in cerebrospinal fluid and serum in clinical high risk for psychosis, first-episode psychosis, and healthy volunteers. Front Psychiatry. (2021) 12:654602. doi: 10.3389/fpsyt.202 1.654602

24. Broderick JP, Adeoye O, Elm J. Evolution of the modified rankin scale and its use in future stroke trials. Stroke. (2017) 48:2007-12. doi: 10.1161/STROKEAHA.117.017866

25. Van Swieten JC, Koudstaal PJ, Visser MC, Schouten HJ, van Gijn J. Interobserver agreement for the assessment of handicap in stroke patients. Stroke. (1988) 19:604-7. doi: 10.1161/01.STR.19.5.604

26. Martinez-Hernandez E, Guasp M, García-Serra A, Maudes E, Ariño H, Sepulveda $M$, et al. Clinical significance of anti-NMDAR concurrent with glial or neuronal surface antibodies. Neurology. (2020) 94:e2302-10. doi: 10.1212/WNL.0000000000009239

27. Safadi AL, Wang T, Maria GD, Starr A, Delasobera BE, Mora CA, et al. Recurrent thymoma-associated paraneoplastic encephalitis resulting from multiple antibodies: a case report. Neurohospitalist. (2020) 10:139-42. doi: $10.1177 / 1941874419880423$

28. Quaranta G, Maremmani AG, Perugi G. Anti-AMPA-receptor encephalitis presenting as a rapid-cycling bipolar disorder in a young woman with turner syndrome. Case Rep Psychiatry. (2015) 2015:273192. doi: 10.1155/2015/273192

29. Adell A. Brain NMDA receptors in schizophrenia and depression. Biomolecules. (2020) 10:947. doi: 10.3390/biom10060947

30. Cleland N, Lieblich S, Schalling M, Rahm C. A 16-year-old girl with antiNMDA-receptor encephalitis and family history of psychotic disorders. Acta Neuropsychiatr. (2015) 27:375-9. doi: 10.1017/neu.2015.32

31. Nakajima H, Unoda K, Hara M. Severe relapse of anti-NMDA receptor encephalitis 5 years after initial symptom onset. eNeurologicalSci. (2019) 16:100199. doi: 10.1016/j.ensci.2019.100199

32. Xu X, Lu Q, Huang Y, Fan S, Zhou L, Yuan J, et al. Anti-NMDAR encephalitis: a single-center, longitudinal study in China. Neurol Neuroimmunol Neuroinflamm. (2020) 7:e633. doi: 10.1212/NXI.0000000000000633

33. Kayser MS, Dalmau J. Anti-NMDA receptor encephalitis in psychiatry. Curr Psychiatry Rev. (2011) 7:189-93. doi: 10.2174/157340011797183184

34. Wei YC, Liu CH, Lin JJ, Lin KJ, Huang KL, Lee TH, et al. Rapid progression and brain atrophy in anti-AMPA receptor encephalitis. J Neuroimmunol. (2013) 261:129-33. doi: 10.1016/j.jneuroim.2013.05.011

35. Prüss H, Höltje M, Maier N, Gomez A, Buchert R, Harms L, et al. IgA NMDA receptor antibodies are markers of synaptic immunity in slow cognitive impairment. Neurology. (2012) 78:1743-53. doi: 10.1212/WNL.0b013e318258300d

36. Rosenthal-Simons A, Durrant AR, Heresco-Levy U. Autoimmuneinduced glutamatergic receptor dysfunctions: conceptual and psychiatric practice implications. Eur Neuropsychopharmacol. (2013) 23:1659-71. doi: 10.1016/j.euroneuro.2013.05.008

37. Van Obberghen EK, Cohen M, Rocher F, Lebrun-Frenay C. Multiple immune disorders after natalizumab discontinuation: After the CIRIS, the SIRIS. Rev Neurol. (2017) 173:222-4. doi: 10.1016/j.neurol.2017.03.008

38. Jones BE, Tovar KR, Goehring A, Jalali-Yazdi F, Okada NJ, Gouaux E, et al. Autoimmune receptor encephalitis in mice induced by active immunization with conformationally stabilized holoreceptors. Sci Transl Med. (2019) 11:eabh4284. doi: 10.1126/scitranslmed.aaw0044

39. Venkatesan A, Benavides DR. Autoimmune encephalitis and its relation to infection. Curr Neurol Neurosci Rep. (2015) 15:3. doi: 10.1007/s11910-015-0529-1

40. Vogrig A, Muñiz-Castrillo S, Desestret V, Joubert B, Honnorat J. Pathophysiology of paraneoplastic and autoimmune encephalitis: genes, infections, and checkpoint inhibitors. Ther Adv Neurol Disord. (2020) 13:1756286420932797. doi: 10.1177/1756286420932797

41. Dalmau J, Tüzün E, Wu HY, Masjuan J, Rossi JE, Voloschin A, et al. Paraneoplastic anti-N-methyl-D-aspartate receptor encephalitis associated with ovarian teratoma. Ann Neurol. (2007) 61:25-36. doi: 10.1002/ana.21050

42. Chater TE, Goda Y. The role of AMPA receptors in postsynaptic mechanisms of synaptic plasticity. Front Cell Neurosci. (2014) 8:401. doi: $10.3389 /$ fncel.2014.00401

43. Haselmann H, Mannara F, Werner C, Planagumà J, Miguez-Cabello F, Schmidl L, et al. Human autoantibodies against the AMPA receptor subunit GluA2 induce receptor reorganization and memory dysfunction. Neuron. (2018) 100:91-105.e9. doi: 10.1016/j.neuron.2018.07.048

44. Laurido-Soto O, Brier MR, Simon LE, McCullough A, Bucelli RC, Day GS. Patient characteristics and outcome associations in AMPA receptor encephalitis. J Neurol. (2019) 266:450-60. doi: 10.1007/s00415-018-9153-8

45. Ashok VR, Nagabushana D, Yashwanth G, Mahadevan A, Netravathi M. A rare case of wobbly, psychotic patient with frozen eyes - anti-AMPA receptor encephalitis. Neurol India. (2021) 69:149-52. doi: 10.4103/0028-3886. 310087

46. Titulaer MJ, McCracken L, Gabilondo I, Armangué T, Glaser C, Iizuka T, et al. Treatment and prognostic factors for long-term outcome in patients with antiNMDA receptor encephalitis: an observational cohort study. Lancet Neurol. (2013) 12:157-65. doi: 10.1016/S1474-4422(12)70310-1

47. Broadley J, Seneviratne U, Beech P, Buzzard K, Butzkueven H. Prognosticating autoimmune encephalitis: a systematic review. J Autoimmun. (2019) 96:24-34. doi: 10.1016/j.jaut.2018.10.014 
48. Zhang Y, Huang HJ, Chen WB, Liu G, Liu F, Su YY. Clinical efficacy of plasma exchange in patients with autoimmune encephalitis. Ann Clin Transl Neurol. (2021) 8:763-73. doi: 10.1002/acn 3.51313

Conflict of Interest: The authors declare that the research was conducted in the absence of any commercial or financial relationships that could be construed as a potential conflict of interest.

Publisher's Note: All claims expressed in this article are solely those of the authors and do not necessarily represent those of their affiliated organizations, or those of the publisher, the editors and the reviewers. Any product that may be evaluated in this article, or claim that may be made by its manufacturer, is not guaranteed or endorsed by the publisher.

Copyright (c) 2022 Luo, Li, Jiang, Tan, Qin, Xiao, Wang, Wang, Yi, Li, Yuan, Liu and Xiao. This is an open-access article distributed under the terms of the Creative Commons Attribution License (CC BY). The use, distribution or reproduction in other forums is permitted, provided the original author(s) and the copyright owner(s) are credited and that the original publication in this journal is cited, in accordance with accepted academic practice. No use, distribution or reproduction is permitted which does not comply with these terms. 